\title{
BIOLOGICAL VALUE AND MORPHOLOGICAL TRAITS OF POLLEN OF SELECTED GARLIC SPECIES ALLIUM L.
}

\author{
Beata Żuraw \\ Department of Botany, Agricultural University, 20950 Lublin, Akademicka str. 15 \\ e mail: beata.zuraw@ar.lublin.pl
}

Received: 20.04 .2007

S u m m a r y

This study was conducted in the years 1997 1999. From the collection of the UMCS Botanical Garden, nine species of garlic were selected (A. aflatunense, A. atropurpureum, A. caeruleum, A. cernuum, A. ledebourianum, A. lineare, A. sphaerocephalon, A. victorialis, A. ursinum) and one subspecies (A. scorodoprasum subsp. jajlae). Pollen grain viability was evaluated on microscopic slides stained with acetocarmine, germination abi lity on the agar medium and measurements of grains were made on glycerin jelly slides. The studied species were characterized by high pollen viability ( $8799 \%$ ) what indicates the great value of garlic flowers as a source of protein rich feed for honey bee and wild pollinating insects. Very low germination of pollen on the agar medium was recorded. The length of the equatorial lon gitudinal axis ranged from $24.3 \mu \mathrm{m}$ to $37.5 \mu \mathrm{m}$ and it allowed pollen of most garlic species to be classified as medium sized grains and only the pollen of A. caeruleum and A. cernuum was included in the group of small sized grains.

Key words: garlic (Allium L.), pollen grain morphology, viability, germination

\section{INTRODUCTION}

The genus Allium L. is the most important among 30 others belonging to the family Alliaceae classified in the order Asparagales (D a h1gren et al., 1985, S mets et al., 2000). This genus includes 700 species and subspecies inhabiting the Northern Hemisphere (Frits ch and Frisen, 2002). Plants from this genus form tubers or bulbs. Flower stems reach the height from several centimeters up to one and a half meter. In Poland 9 species grow in deciduous forests and dry meadows. Some are typical weeds (Allium carinatum, A. vineale). Six species are in danger of extinction, e.g. A. ursinum and $A$. victorialis ( $Z$ arzy cki et al., 2002). Flowers are gathered in an umbrella type inflorescence. Colors vary from white (A. neapolitanum, A. ursinum), through pink
(A. cernuum), violet (A. aflatunense) to purple (A. atropurpureum). Some species form blue (A. caeruleum) or yellow flowers (A. moly, A. flavum). Most species are grown for cut flowers or as ornamentals on flower beds due to winter hardiness and low nutritional requirements (Krzymińska, 2003). Flower easily set seeds. Seeds should be sown to the seed-bed in the autumn or directly to the soil in the spring (Kamenetsky and Gutter$\operatorname{man}, 2000)$. The easiest way of propagation is the division of adventitious bulbs that should be set from the middle of September up to middle of November.

Flowers of species from the genus Allium L. might be a valuable source of nectar and pollen for honeybee and wild insects (Lipiński, 1982). Szklanowska (1982) observed honeybee pollen-collectors forming small pollen loads on flowers of A. flavum and A. pulchellum.

The aim of this research was the evaluation of pollen grain viability, germination strength, the study of the pollen grain morphology with a focus on the pollen grain size.

\section{MATERIALS AND METHODS}

Observations were made in the years 1997-1999 in the Botanical Garden of the UMCS University in Lublin. Pollen samples were collected from flowers of nine garlic species ( $A$. aflatunense $\mathrm{B}$. Fedtsh, $A$. atropurpureum W. Et K., A. caeruleum Pall., A. cernuum Roth., A. ledebourianum Roem. et Schult, $A$. lineare L., A. sphaerocephalon L., A. victorialis L., A. ursinum L.) and its subspecies (A. scorodoprasum subsp. jajlae (Vved.) Stern). For each taxon in each year, at the beginning, in the middle and at the end of flowering, 4 acetocarmine stained microscopic slides were prepared and viable pollen grains (with the protoplast stained) were counted. Means for each set of information were calculated. Measurements of pollen grains 
were made on glycerin jelly slides. In the polar position, the length of the equatorial longitudinal axis was measured (EL). In the equatorial position, the equatorial transversal axis (ET) and the polar axis (P) were measured. Next, shape coefficients defining the degree of side constriction (EL/ET) and flattening (P/EL) of the grains were calculated. Means for results from three years were calculated. To study the germination strength of pollen grains in the year 1999, samples in the mid of flowering were collected and sown on the agar medium. Plates were placed in the controlled environment. After one hour germination energy and after 24 hours germination ability of the pollen grains were evaluated.
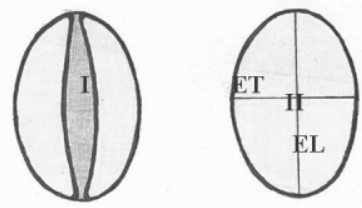

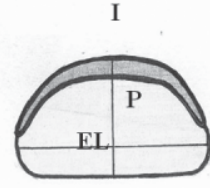

II

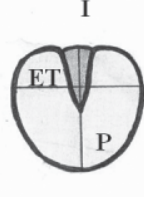

Fig. 1. Diagram of garlic pollen grains

A polar position, B equatorial position

I distal side, II proximal side

$\mathrm{P}$ polar axis, EL equatorial longitudinal axis,

ET equatorial transverse axis

Table 1

Pollen grain sizes and shapes of garlic (Allium L.) species (averages from the years 1997 1999).

\begin{tabular}{|c|c|c|c|c|c|c|c|c|}
\hline \multirow{4}{*}{ Species } & \multicolumn{8}{|c|}{ Axis length $(\mu \mathrm{m})$} \\
\hline & \multirow{2}{*}{\multicolumn{2}{|c|}{ Polar axis $(\mathrm{P})$}} & \multicolumn{4}{|c|}{ Equatorial axis (E) } & \multirow{2}{*}{\multicolumn{2}{|c|}{ Coefficient }} \\
\hline & & & \multicolumn{2}{|c|}{ longitudinal (EL) } & \multicolumn{2}{|c|}{ transversal $(\mathrm{ET})$} & & \\
\hline & $\begin{array}{l}\min \\
\max \end{array}$ & Mean & $\min \max$ & Mean & $\min \max$ & Mean & $\mathrm{EL} / \mathrm{ET}$ & $\mathrm{P} / \mathrm{EL}$ \\
\hline $\begin{array}{l}\text { Allium aflatunense } \\
\text { B. Fedtsch }\end{array}$ & 1825 & $22.00_{d}$ & 2332 & $30.90_{b}$ & 1823 & $19.70_{\mathrm{c}}$ & $1.60_{c}$ & $0.70_{\mathrm{c}}$ \\
\hline $\begin{array}{c}\text { Allium atropurpureum } \\
\text { W. et K. }\end{array}$ & 1621 & $19.50_{b}$ & 2832 & $32.10_{\mathrm{cd}}$ & 1621 & $18.10_{b}$ & $1.77_{\mathrm{d}}$ & $0.67 \mathrm{bc}$ \\
\hline Allium caeruleum Pall. & 1218 & $15,00_{\text {a }}$ & 2325 & $24.30_{\text {a }}$ & 1618 & $16.60_{a}$ & 1.47 a & $0.63_{\mathrm{abc}}$ \\
\hline Allium cernuum Roth. & 1218 & $15.10_{\mathrm{a}}$ & 2326 & $24.75_{a}$ & 1619 & $17.00_{\mathrm{a}}$ & $1.46_{\mathrm{a}}$ & $0.63 a b c$ \\
\hline $\begin{array}{l}\text { Allium ledebourianum Roem. } \\
\text { et Schult. }\end{array}$ & 1825 & $21.00_{c}$ & 3237 & $34.10_{\mathrm{fg}}$ & 2125 & $21.70_{\mathrm{e}}$ & $1.57 \mathrm{bc}$ & $0.60_{\mathrm{ab}}$ \\
\hline Allium lineare $\mathrm{L}$. & 2130 & $24.53 \mathrm{e}$ & 3539 & $37.50_{h}$ & 2125 & $23.70_{f}$ & $1.60_{\mathrm{c}}$ & $0.67 \mathrm{bc}$ \\
\hline $\begin{array}{c}\text { Allium scorodoprasum subsp. } \\
\text { jajlae } \\
\text { (Vved.) Stearn }\end{array}$ & 1625 & $20.83_{\mathrm{c}}$ & 3035 & $31.27 \mathrm{bc}$ & 1823 & $20.23_{c}$ & $1.57 \mathrm{bc}$ & $0.67 \mathrm{bc}$ \\
\hline Allium sphaerocephalon L. & 1723 & $19.27 \mathrm{~b}$ & 3237 & $33.43_{\text {ef }}$ & 1823 & $20.86_{d}$ & $1.60_{\mathrm{c}}$ & 0.57 a \\
\hline Allium ursinum L. & 1823 & $20.50_{c}$ & 3035 & $32.86_{\mathrm{de}}$ & 2123 & $21.57_{\mathrm{e}}$ & $1.50_{\mathrm{ab}}$ & $0.60_{\mathrm{ab}}$ \\
\hline Allium victorialis $\mathrm{L}$. & 2128 & $21.57 \mathrm{~cd}$ & 3237 & $34.77_{\mathrm{g}}$ & 2123 & $21.47_{\mathrm{e}}$ & $1.60_{c}$ & 0.63 \\
\hline Mean & & 20.5 & & 32.1 & & 20.3 & 1.60 & 0.60 \\
\hline
\end{tabular}

Means followed by the same letters are not significantly different at $\alpha \quad 0.05$ by Duncan test. 


\section{RESULTS}

The pollen grain of garlic is heteropolar. It has two plains of symmetry and its equatorial axes are not equal. The equatorial longitudinal axis (EL) is longer than the polar axis $(\mathrm{P})$ what gives the grain a flattened shape (Fig. 1). A significant difference in the length of the equatorial longitudinal axis (EL) and the equatorial transversal axis (ET) results in the side constriction of the grain. There is a long furrow on the distal surface of the grain. Exine is smooth or slightly netted.

In the study, the length of the polar longitudinal axis $(\mathrm{P})$ of the grains differed significantly between species in the range from $15.0 \mu \mathrm{m}$ to $24.5 \mu \mathrm{m}$ (Tab. 1). A. caeruleum $(15.0 \mu \mathrm{m})$ and $A$. cernuum $(15.1 \mu \mathrm{m})$ had the most flattened grains, and $A$. lineare $(24.5 \mu \mathrm{m})$ had the most convex grains. The longitudinal equatorial axis was the longest dimension of the grain. On the basis of this trait, the studied species were divided into three groups. The group of the smallest grains $(24.3-24.8 \mu \mathrm{m})$ included A. caeruleum and A. cernuum. The second group of grains between $30.9 \mu \mathrm{m}$ and $34.8 \mu \mathrm{m}$ in length comprised seven of the studied species. Allium lineare was classified separately due to the longest $(37.5 \mu \mathrm{m})$ pollen grains. The dimensions of the equatorial transversal axis (ET) of the pollen varied in the range of $16.6 \mu \mathrm{m}$ to 23.7 $\mu \mathrm{m}$. The coefficient describing the relation between the length of the equatorial longitudinal axis and the equatorial transversal axis (EL/ET) defined side constriction of the grains. The constriction of grains was the biggest in $A$. atropurpureum (1.77), the most oval shape in polar position characterized grains of $A$. cernuum, $A$. caeruleum and $A$. ursinum $(1.46-1.50)$. The ratio of the polar to equatorial longitudinal axes lengths $(\mathrm{P} / \mathrm{EL})$ in the range between 0.57 and 0.67 indicates a significant flattening of pollen grains of different Allium species.

Table 2

Viability of pollen (in \%) of garlic (Allium L.) species (data from the years 1997 1999).

\begin{tabular}{|c|c|c|c|c|}
\hline Species & 1997 & 1998 & 1999 & Mean \\
\hline $\begin{array}{l}\text { Allium aflatunense } \\
\text { B. Fedtsch }\end{array}$ & $97.25_{\text {ef }}$ & $94.60_{\text {ef }}$ & $75.75_{a}$ & 89.20 a \\
\hline $\begin{array}{c}\text { Allium atropurpureum } \\
\text { W. et K. }\end{array}$ & 95.37 ef & 96.97 ef & $97.42_{\mathrm{f}}$ & $96.59_{b}$ \\
\hline Allium caeruleum Pall. & $98.25_{\mathrm{f}}$ & $97.65_{\mathrm{f}}$ & $99.12_{\mathrm{f}}$ & $98.34_{b}$ \\
\hline Allium cernuum Roth. & $93.05_{\mathrm{df}}$ & $80.50_{\mathrm{ab}}$ & $90.42_{\text {cf }}$ & $87.99_{\mathrm{a}}$ \\
\hline $\begin{array}{l}\text { Allium ledebourianum } \\
\text { Roem. et Schult. }\end{array}$ & $97.12_{\text {ef }}$ & $99.40_{\mathrm{f}}$ & $87.27 \mathrm{be}$ & $94.60_{b}$ \\
\hline Allium lineare L. & $99.15_{\mathrm{f}}$ & $98.50_{\mathrm{f}}$ & $98.42_{\mathrm{f}}$ & $98.69_{b}$ \\
\hline $\begin{array}{c}\text { Allium scorodoprasum } \\
\text { subsp. jajlae (Vved.) Stearn }\end{array}$ & $77.30_{\text {a }}$ & $95.60_{\text {ef }}$ & $89.12_{b f}$ & $87.34_{\mathrm{a}}$ \\
\hline Allium sphaerocephalon L. & $96.00_{\text {ef }}$ & $84.100_{a d}$ & $82.90_{\mathrm{ac}}$ & $87.63_{\mathrm{a}}$ \\
\hline Allium ursinum $\mathrm{L}$. & $95.87_{\text {ef }}$ & $96.50_{\text {ef }}$ & $97.50_{\mathrm{f}}$ & $96.62_{b}$ \\
\hline Allium victorialis $\mathrm{L}$. & $97.20_{\mathrm{de}}$ & $96.25_{\mathrm{de}}$ & $97.52_{\mathrm{de}}$ & $96.99_{b}$ \\
\hline Mean & $94.66_{b}$ & $94.100_{\mathrm{ab}}$ & $91.55 \mathrm{a}$ & \\
\hline
\end{tabular}

Means followed by the same letters are not significantly different at $\alpha \quad 0.05$ by Duncan test. 
Table 3

Germination and potential energy (in \%) of pollen of six garlic species in 1999.

\begin{tabular}{|c|c|c|c|}
\hline Species & $\begin{array}{c}\text { Germination energy } \\
\text { after one hour }\end{array}$ & $\begin{array}{c}\text { Germination ability } \\
\text { after 24 hour }\end{array}$ & Potential energy \\
\hline $\begin{array}{c}\text { Allium aflatunense } \\
\text { B. Fedtsch }\end{array}$ & 1.75 & 26.83 & 35.42 \\
\hline Allium cernuum Roth. & 0.17 & 0.25 & 0.28 \\
\hline $\begin{array}{c}\text { Allium ledebourianum } \\
\text { Roem. et Schult. }\end{array}$ & 0.25 & 0.42 & 0.44 \\
\hline $\begin{array}{c}\text { Allium scorodoprasum } \\
\text { subsp. } \text { jajlae (Vved.) Stearn }\end{array}$ & 0.00 & 1.08 & 3.24 \\
\hline Allium ursinum L. & 0.92 & 2.50 & 35.29 \\
\hline Allium victorialis L. & 11.75 & 34.42 & 12.64 \\
\hline Average & 2.47 & 10.92 & 3.20 \\
\hline
\end{tabular}

The percentage share of viable protoplast pollen grains was high in the case of all garlic species (Tab. 2). Four species demonstrated viability from $87.3 \%$ to $89.2 \%$ (A. scorodoprasum subsp. jajlae, A. sphaerocephalon, A. cernuum, A. aflatunense) and six from $94.6 \%$ to $98.7 \%$ (A. ledebourianum, A. atropurpureum, A. ursinum, A. victorialis, $A$. caeruleum, A. lineare). Independently of the species, the highest share of grains with the protoplast well stained with acetocarmine was observed in the first year $(94.7 \%)$. Significantly less in the last year of the study $(91.6 \%)$. The share of viable grains could have been influenced by meteorological conditions during flowering, especially by rains that were four times more intensive in June 1997 than in June 1999.

On the agar medium, garlic pollen grains germinated very weakly or did not form tubes at all. After one hour, tubes of only six species formed pollen and germination ability was on average $2.5 \%$ (Tab.3). After 24 hours, potential energy of the pollen was on average $10.9 \%$ and only in the case of $A$. victorialis it reached $35 \%$.

\section{DISCUSION}

Pollen grains in the study were characterized by a smaller range of equatorial longitudinal axis length (24-38 $\mu \mathrm{m})$ compared to data of Kuprianova (1983) $(22-60 \mu \mathrm{m})$. Also, the dimensions of the polar axis were in a significantly smaller range $(15-25 \mu \mathrm{m})$. The length of both the equatorial axis and the polar axis of the studied species was within the limits defined by Moor et al. (1991). According to them, any of the Allium pollen grain axes is not longer than $50 \mu \mathrm{m}$. The dimensions of
A. ursinum pollen grains in the polar position $(21.6 \times 32.9$ $\mu \mathrm{m})$ were within the limits $(19.5 \times 32.0-25.5 \times 38.5 \mu \mathrm{m})$ given by Stachurska et al. (1973). In the polar position, an elliptical shape of pollen grains was observed, similarly to the description given by Tolgor (1995). Data concerning the dimensions and shape of pollen grains of all species were consistent with the descriptions given by Erdtman (1956). Generally, pollen viability was in the range between $87 \%$ (A. sphaerocephalon) and $99 \%$ (A. lineare). A significant influence of intensive rainfall at the period of flowering on the value of this trait was observed.

The interest of pollinating insects in flowers of the studied species indicated a high nutritional value of the pollen.

\section{REFERENCES}

Dahlgren R. M. T., Clifford H.T., Yeo P. F., 1985. The families of the Monocotyledons. Springer Verlag, Berlin, Heidelberg, New York, Tokyo.

Erdtman G., 1956. Morfologia pylcy i sistiematika rastienij. I Pokrytosiemiennyje. Izdatielstvo Innostrannoj Litiera tury, Moskva.

Fritsch R., Friesen N., 2002. Chapter 1. Evolution, Domes tication and Taxonomy. W: H.D. Rabinovitch and L. Cur rach (eds.) Allium Crop Science Recent Advances. CABI Publishing: 527.

Kamenetsky R., Gutterman Y., 2000. Germination stra tegies of some Allium species of the subgenus Melanocrommyum from arid zone of Central Asia. Journal of Arid Enviromnents, 45: 6171. 
Krzymińska A., 2003. Fenologia i morfologia wybranych gatunków ozdobnych czosnku (Allium L.). / Phenol ogy and morphology of selected ornamental species of garlic(Allium L.). Zesz. Problem. Nauk Roln. 491: 161168.

Kuprianova A., 1983. Spory paporotnikoobraznich i pylcy go łosiemiennych i odnodolnych rastienij flory ēvropejskoj čiasti SSSR. Akad. Nauk SSSR. Leningrad.

Lipiński M., 1982, Pożytki pszczele, zapylanie i miododaj ność roślin. / Pollen flows, pollination and honey yield of plants. PWRiL, Warszawa.

Moore P.D., Webb J. A., Collinson M. E., 1991. Pollen Analysis. Blackwell Scientific Publications, Oxford.

Mroczko R., Morawska I., Szlachetka W., 2000. Wpływ uprawy czosnków ozdobnych w gruncie i w tunelu folio wym na plon cebul. / The influence of ornamental garlic crops grown in open field and in a plastic tunnel on onion yield. Biul. Stow. Prod. Ozdob. Roślin Ceb., 11: 1821.

Smets E. F., Ronse Decraene L. P., Caris P., Rudall P. J., 2000. Floral Nectaries in Monocotyledons: Dis tribution and Evolution. In: Monocots: Systematic and Evolution. Eds K.L. Wilson, D.A. Morrison. CSIRO. Melbourne: 230240.

Stachurska A., Sadowska A., Kuszell T., 1973. Kartoteka palinologiczna roślin polskich. / Palynological card index of Polish plants. Zesz. Przyrodn., 23: tablica 286.

Szklanowska K., 1982. Wartość pszczelarska i owocowanie niektórych gatunków z rodzaju Allium L. / Mellifer ous value and fruiting of certain species from the genus Allium L. Studia i Materiały III Seminarium „Zapylanie roślin warzywniczych”, Skierniewice: 216243.

Tolg or M., 1995. Pollen morphology of Allium and its taxonom ic significance. Journal of Jilin Agricultural University, 17, 1: 3640 .
Zarzycki K., Trzcińska Tacik H., Różański W., Sze ląg Z., Wołek J., Korzeniak U., 2002. Ecological indicator values of vascular plants of Poland. W. Szafer Institute of Botany, Polish Academy of Science. Kraków.

\section{Wartość biologiczna i morfologiczne cechy pyłku wybranych gatunków czosnku (Allium L.)}

\section{Streszczenie}

Badania prowadzono w latach 1997-1999. Z kolekcji roślin jednoliściennych Ogrodu Botanicznego UMCS w Lublinie wytypowano dziewięć gatunków czosnku (Allium aflatunense, A. atropurpureum, A. caeruleum, A. cernuum, A. ledebourianum, A. lineare, A. sphaerocephalon, A. victorialis, A. ursinum) i jeden podgatunek (A. scorodoprasum subsp. jajlae). Żywotność ziaren pyłku oceniano w preparatach $\mathrm{z}$ acetokarminem, zdolność kiełkowania na pożywce agarowej, natomiast pomiary ziaren wykonano w preparatach gliceryno-żelatynowych. Badane gatunki charakteryzowały się wysoką żywotnością ziarn (87-99\%), co wskazuje na znaczną wartość kwiatów czosnku jako źródła pokarmu białkowego dla pszczoły miodnej i dziko żyjących owadów zapylających. Stwierdzono natomiast bardzo niską siłę kiełkowania pyłku na pożywce agarowej. Wymiary podłużnej osi równikowej ziarn w zakresie od $24,3 \mu \mathrm{m}$ do $37,5 \mu \mathrm{m}$ pozwoliły zaklasyfikować pyłek większości gatunków czosnku do ziaren średnich, jedynie ziarna pyłku Allium caeruleum i A. cernuum zaliczono do małych. 
